\title{
Çorum ilinde çeltik üretimi yapan işletmelerin tarımsal mekanizasyon durumu*
}

\author{
Murat BAL ${ }^{1}$, Ebubekir ALTUNTAȘ²
}

${ }^{1}$ Orta Karadeniz Geçit Kuşağı Tarımsal Araştırma Enstitüsü Müdürlüğü, Tokat

2Gaziosmanpaşa Üniversitesi Ziraat Fakültesi Biyosistem Mühendisliği Bölümü, Tokat

*Bu çalışma, Murat BAL tarafından hazırlanan ve 'Çorum ilinin ayçiçeği ve çeltik tarımı yapan işletmelerinin mekanizasyon düzeyinin belirlenmesi' konulu Yüksek Lisans Tezinin bir bölümüdür.

Alınış tarihi: 27 Ağustos 2018, Kabul tarihi: 20 Kasım 2018

Sorumlu yazar: Ebubekir ALTUNTAŞ, e-posta: ebubekir.altuntas@gop.edu.tr

\section{Öz}

Araştırmanın amacı, Çorum ilindeki çeltik üretimi yapan tarım işletmelerinin mekanizasyon düzeyini belirlemektir. Buna yönelik olarak çeltik üretiminin yoğun olarak yapıldığı Osmancık ve Kargı ilçelerindeki 10 köyden toplam 110 işletmede anket çalışması yapılmıştır. Anket, çeltik üreticilerinin tarımsal arazi varlığını, traktör ve tarım makineleri varlığı ile çeltik üretiminde mekanizasyon aşamalarındaki bilgilerini içermektedir. Çalışmada, Çorum ili çeltik üretici işletmelerin tarımsal mekanizasyon düzeyleri, Türkiye ile karşılaştırılmıştır. Ayrıca çeltik tarımında toprak işleme uygulamasından hasat işlemlerine kadar geçen tarım uygulamalarındaki mekanizasyon kullanımları incelenerek değerlendirilmiștir. Araştırma sonucunda, çeltik üreticisi işletmelerde ortalama arazi büyüklüğü 7.7 ha, işlenen alan başına traktör gücü $5.40 \mathrm{~kW}, 1000$ hektar alan başına traktör sayısı 125.6 traktör; bir traktör başına tarımsal ekipman sayısı 4.9 adet adet olarak gözlemlenirken, traktör başına düşen işlenen alan ise 7.96 ha olarak bulunmuştur. Bu çalışmanın sonucunda, çeltik üreticisi işletmeler, mekanizasyon düzeyleri açısından Türkiye ortalamasından daha yüksek olmasına rağmen, tarımsal işlemlerde yeterli bir mekanizasyon zincirini tamamlayamamışlardır. Mekanizasyon zincirinin tamamlanmasıly üretim verimliliği artacaktır.

Anahtar kelimeler: Çeltik, tarım işletmesi, traktör, tarım makineleri
The agricultural mechanization level of agricultural enterprises producing paddy in corum province

\begin{abstract}
The purpose of the research is to determine the mechanization status of the agricultural enterprises of the paddy agriculture production in Çorum province. For this purpose, a survey was conducted in 110 enterprises in 10 villages in Osmanclk and Kargl districts where sunflower production were concentrated. The survey includes the presence of land of the producers of the region, the presence of tractor and agricultural machinery and knowledge of the paddy production mechanization phases. In this study, the mechanization levels for paddy productions of Çorum province were compared with Turkey. In addition, all mechanization practices from soil tillage application to harvest were examined for the paddy production. As a result of the research, the values related to the level of mechanization of enterprises in the region; average land sizes were 7.7 ha; tractor power per cultivated area was as $5.40 \mathrm{~kW}$ for paddy producer enterprises, the number of tractors per 1000 ha cultivated area is 125.6 tractors, the number of agricultural machinery per tractor was found as 4.9 number, the cultivated area per tractor area per tractor was obtained as 7.96 ha for paddy producer enterprises. In the result of this study, the paddy producer enterprises failed to complete a chain of adequate mechanization in agricultural operations, although mechanization
\end{abstract}


level was higher than Turkey. With the completion of the mechanization chain, production efficiency will increase.

Key words: Paddy, agricultural enterprise, tractor, agricultural machinery

\section{Giriş}

Tarımdaki mekanizasyonun önemi, teknolojideki gelişmelere bağlı olarak artış göstermiş, böylece tarımsal üretimde birim alandan daha fazla verimin alınması mümkün olmuştur. Tarım sektöründeki teknoloji kullanımı ile işgücü talebi; iklim şartları ve arazi yapısı ile etkilenmektedir. Tarımsal üretimdeki verimlilik artışına neden olan tohum, gübre ve ilaç vb. girdi materyallerinin uyumlu kullanılması için en önemli araçlardan birisini tarımsal mekanizasyon oluşturmaktadır (Özgüven ve ark., 2010).

Tarımsal işletmelerdeki en önemli tarımsal teknoloji girdilerinden birisi oluşturan tarımda makine kullanımının çeşitlendiği günümüzde, makine seçimi ile planlaması artık daha önemli bir duruma gelmiştir. Tarımsal mekanizasyondaki beklenen hedefe ulaşmada ve tarımda verimliliğe daha fazla katkıda bulunulabilmek için tarımsal güç makinelerinin kendilerine en uygun tarımsal alet ve makineler ile donatılması, ayrıca optimal işletmecilik prensiplerinin esas alınması gerekmektedir (Akar, 2015).

Tarımsal mekanizasyon düzeylerinin üretimin yoğun olduğu bitkiler için yapılması, yoğun üretimi yapılan bitkisel üretimdeki verimlilik ile kârlılığın da bir göstergesi olmakta, tarımsal mekanizasyon durumunun belirlenmesi, dünya ülkeleri arasındaki tarımsal gelişmişliğin bir göstergesi olarak da değerlendirilebilmektedir. Tarımsal mekanizasyon durumu, herhangi bir tarımsal işletmede veya ilçe, il, bölge, ülkedeki mekanik güç kaynakları olan traktör ile tarım alet-makine ve ilgili sistemlerin kullanımına ait bilgileri içermektedir. Tarımsal mekanizasyon durumunu belirlemek için; işletmelerin alansal büyüklükleri, traktör güç gruplarının uyumuyla beraber tarım alet- makinelerin sayısal yoğunluğu gözönüne alınmaktadır. Mekanizasyon durumunun belirlenmesinde; birim tarım alanına düșen traktör gücü $(\mathrm{kW}$ ha-1), birim traktöre düşen tarımsal alan (ha traktör-1 ${ }^{-1}$, birim tarımsal alana düşen traktör sayısı (traktör 1000 ha $^{-1}$ ), birim traktöre düșen makine sayısı (adet traktör-1) hesaplanmaktadır (Altuntaş ve Arslan, 2009). Türkiye bugünkü sahip olduğu tarımsal mekanizasyon düzeyi ile, $\mathrm{AB}$ ülkelerine göre yeterli düzeyde olmadığı gibi, ülke içinde de, bölgesel düzeyde belirli farklılıklar görülmektedir. AB'de tarım sektörünün Gayri Safi Milli Hasıla içerisindeki payı \%1,9 iken, Türkiye'de ise \%7.6; Türkiye'de tarımsal nüfusun istihdamdaki payı ise \%27.3 iken, $A B^{\prime} d e$ ise bu pay $\% 5,9$ düzeyindedir. Her geçen yll artan tarımsal ürün talebini karşılamak için, mevcut üretim miktarının arttırılmasıyla beraber ürün veriminin yükseltilebilmesine ihtiyaç duyulmaktadır (İleri, 2009; Özgüven ve ark., 2010).

Bir çok araştırmacı tarafından, Türkiye geneline yönelik, bölgeler bazında veya farklı il ve ilçelerine yönelik tarımsal mekanizasyon durumunun belirlenmesine yönelik çalışmalar yapılmış ve bu çalışmaların, güncel veriler dikkate alınarak her geçen gün yenileri yapılmakta olup, bu çalışmalar, yöre, bölge ve Türkiye'nin durumunu ve geleceğe yönelik projeksiyonunu ortaya koymaya yardımcı olmaktadır (Çalışır ve ark., 1991; Zeren ve ark., 1995; Kasap ve ark., 1997; Topuz, 1997; Çiçek ve Çelen, 2000; Işık ve ark., 2003; Durgut ve Arın, 2005; Yazıcı, 2006; Ünal ve Saçılık, 2007; Dartar ve Say, 2008; Altuntaş ve Arslan, 2009; Demir ve Öztürk, 2011).

Çeltik tarımı, küresel tarımsal alanın yaklaşık olarak \%10'unda (161 milyon hektar) yaplmakta olup, Dünya çeltik ekim alanları daha çok Asya kıtasında (Çin'de 30 milyon ha, Hindistan'da 44 milyon ha, Endonezya'da 12 milyon ha, Bangladeş'te 12 milyon ha ve Tayland'da 11 milyon ha) bulunmaktadır. Çin, Hindistan ve Endonezya, dünya çeltik ekim alanlarının \%50'sinden daha fazlasına sahiptir (Anonim, 2016). Türkiye ülke olarak çeltik ile pirinç açısından ithalatçı ülke olmasına karşın, özellikle 2000 yılı sonrası uygulanan tarımsal politika ve yapılan desteklemeler ile beraber kaliteli ve yüksek verimli çeşitler kullanımı, çeltik üreticisi işletmelerin modern tarım tekniklerini kullanması ve yetiştirme tekniklerinin iyileştirilmesiyle çeltik üretiminde ciddi artışlar sağlamıştır. 2007 yılı için 94000 hektar ekili alanından 648000 ton üretim ve 6.9 ton ha-1 verim elde edilirken, 2016 yılında ise 116056 hektar ekili alandan 920000 ton üretim ile beraber 7.93 ton ha $^{-1}$ verim elde edilebilmiştir. Çeltik ekim alanları, üretim miktarı ve ürün veriminde böylece ciddi orandaki artışlar gözlenmiş, verim artışı 2000-2016 yılı arasında \%32 oranında gerçekleşmiştir (Anonim, 2016). Türkiye'de çeltik üretiminin tüketimi karşılayamamasından dolayı, çeltik veya pirinç ithalatı söz konusu olup, kişi başı tüketimdeki önemli 
artışlar olmazsa, çeltik ekim bölgelerindeki yapılan barajların kullanıma açılmasıyla yakın gelecekte, çeltik üretiminde Türkiye kendi kendine yeter duruma gelebilecek ve ihracatçı ülke olabilecek potansiyeli taşımaktadır. Çeltik ürünü, birim alandaki kârlılık açısından diğer birçok ürüne göre daha avantajlı bir tarım ürünüdür (Anonim, 2016). Çeltik, Türkiye tahıl ekili alanlar arasında \%1.1 ve üretimde ise \%2.6 paya sahip olup, 2016 yılı verilerine göre Türkiye'de çeltik tarımı toplam 27 ilde 116000 hektar alanda yapılmakta, ekim alanı ve üretim açısından Marmara Bölgesi \%71'lik üretimle ilk sırada yer almakta, Karadeniz Bölgesi \%24'lük bir üretim payına sahip, bu iki bölge, toplam üretimin \%95'ini gerçekleştirmektedir. Toplam üretimin \%5'lik kısmı sırasıyla \%3, \%1 ve \%1'lik paylarda sırasıyla İç Anadolu, Güneydoğu Anadolu ve diğer bölgeler tarafından karşılanmaktadır. Çeltik üretimi il bazında başlıca Edirne (\%41), Samsun (\%14), Balıkesir (\%12), Çanakkale (\%9) ve Çorum (\%6)'lık bir paylara sahip olup, bu illerin üretimleri, toplam üretimin \%82'sini oluşturmaktadır (Anonim, 2016).

Çeltik üretiminin Karadeniz bölgesinde yer alan Çorum ilinde önemli bir tarımsal potansiyeli mevcuttur. Tarımsal üretimin arttırılmasında yeni tarım alet ve makine kullanımlarının önemli bir etkisi bulunmaktadır. Çiftçilerin üretimde kullandıkları traktör ve tarım alet-makinelerinin mevcut durumu, kullanım etkinliği ve yeterliliğinin belirlenmesi bu anlamda gereklidir. Daha önceki literatür taramalarında sınırlı sayıda bitkisel üretim desenine ait örneğin şeker pancarı (Yazıcı, 2006), zeytin (Topuz, 1997), çeltik (Bayhan, 1993), buğday (Chimeddamba, 2012) gibi ürünlere ilave olarak bağlarda (Durgut ve Arın, 2005) mekanizasyon etkinliğinin araștırıldığı çalıșmalar mevcuttur. Çorum ili özellikle Orta Anadolu ile Karadeniz geçit bölgesinde yer almakta olup, yöreye ait mekanizasyon düzeyinin bilinmesi ve sorunların çözümüne yönelik önlemlerin belirlenmesi gerekmektedir. Bu çalışmada, Çorum ilinde çeltik üretiminin yoğun bir şekilde yapılıyor olmasından dolayı, Çorum ilindeki en fazla üretim yapan işletmeler dikkate alınarak bu işletmelerin çeltik üretimlerindeki mekanizasyon düzeyleri anket çalışması ile araştırılmıştır. Ayrıca Çorum ilinin genel mekanizasyon durumu (birim tarım alanına düşen traktör gücü (kW ha-1), birim traktöre düşen tarımsal alan (ha traktör-1), 1000 ha tarım alanına düşen traktör sayısı (traktör $1000 \mathrm{ha}^{-1}$ ), birim traktöre düşen makine sayısı (adet traktör ${ }^{-1}$ ) belirlenerek, Çorum ili ve Türkiye geneline göre de karşılaştırmalar yapılmıştır.

\section{Materyal ve Yöntem}

\section{Materyal}

$\mathrm{Bu}$ çalışmanın ana materyalini anket çalışmasından derlenen veriler oluşturmaktadır. Makale, Bal (2018) tarafından yapılan ve konusu, Çorum ilinde ayçiçeği ve çeltik üretiminin en fazla yapıldı̆̆ mekanizasyon düzeylerinin belirlenmesi olan yüksek lisans tez çalışmasının bir bölümü niteliğindedir. Araştırmanın örnek hacmi tez çalışması düzeyinde hem çeltik hem de ayçiçeği üreticileri de dahil olmak üzere 363 olarak belirlenmiş olup, bu makalede yalnızca çeltik üreticilerine ilişkin veriler kapsama alınmıştır. Bu kapsam dahilinde makalede, Çorum ili Kargı ve Osmancık ilçelerinde seçilen on köyde çeltik üretimi yapan 110 çiftçi ile gerçekleştirilen anket verileri kullanılmıştır. 2016 yılı üretim sezonunda yapılan anket çalışması verilerinin yanı sıra, araştırma bölgesindeki İl/İlçe Tarım ve Orman Müdürlükleri ve Türkiye İstatistik Kurumu (TÜİK, 2016) kaynaklarından derlenen istatistiki bilgiler ve konu ile ilgili daha önce yapılmış çalışmaların sonuçları da, çalışmanın ikincil nitelikli verilerini oluşturmuştur.

\section{Yöntem}

Örnekleme çalışmasının ilk aşamasında, bu iki ürünü en çok yetiştiren ilçeler ve bu ilçelerde en çok yetiştiren köyler seçilerek, örneklem alanı Gayeli Örnekleme Yöntemine göre sinırlandırılmıştır. Bunun için Çorum ili ve ilçelerine bağlı köylerdeki ayçiçeği ve çeltik üreticisi tarım işletmesi sayıları belirlenmiştir. Bu sayılar esas alınarak, ayçiçeği için göreceli olarak üretim ve işletme sayıları yoğun olan Mecitözü ve Merkez ilçelerinde toplam 10 köy ile çeltik için Kargı ve Osmancık ilçelerinde 10 köy olmak üzere toplamda bu 4 ilçeye bağlı 20 köyde çalışılmaya karar verilmiştir. Örnekleme çalışmasının ikinci aşamasında, seçilen köylerdeki toplam işletme sayıları ve örnek hacimleri "Belirli Evrenler İçin Kabul Edilebilir Örnek Büyüklükleri” dikkate alınarak tespit edilmiştir (Altunışık ve ark., 2012). "Belirli Evrenler İçin Kabul Edilebilir Örnek Büyüklükleri" tablosunda, 20 köyde bulunan işletmelerin oluşturduğu ana kütle büyüklüğü için, $\% 95$ güven sınırları, \%5 hata payı ile örnek hacmi 345 olarak verilmektedir. Bu sayı, tespit edilmiş olan ana kütle büyüklüğünde, karar verilen güven sınırı (\%95) ve hata payına göre (\%5) temsil yeteneği olan sayıdır. Araștırmada bu sayı \%5 oranında arttırılarak 
363 işletmeye anket uygulanmasına karar verilmiștir. Her köyde yapılacak anket sayısı ise, köylerde ayçiçeği ve çeltik tarımı ile uğraşan toplam üretici sayısının ağırlığına göre belirlenmiştir. Bu şekilde, çeltik üreticiliği yapan köyler için anket sayısı 110 olarak gerçekleşmiştir. Anket yapılacak üreticilerin tespiti ise, her köyde ayçiçeği ve çeltik tarımı yapan üreticiler arasından, İl Tarım ve Orman İl/İlçe Müdürlüğü kayıtlarından yararlanarak rastgele seçilmiştir. Bunun sonrasında hazırlanmış olan anket formları üreticilerle yüz yüze görüşülerek doldurulmuştur. Anket sorularının cevapları, oransal değerlendirmeler yapmak için Microsoft Office Excel programına aktarılmıştır. $\mathrm{Bu}$ değerlendirmelerin sonucunda, tarım işletmelerinin sosyo-ekonomik düzeyleri, tarım alanları durumu, traktör ve tarım makineleri durumu, ayçiçeği ve çeltik üretiminde uygulanan tarımsal uygulamalardaki makine kullanımları dikkate alınarak, tarımsal mekanizasyon düzeyleri ortaya konulmuştur. İşletmelerin mekanizasyon düzeyleri belirlenirken, ayçiçeği ve çeltik üreticileri birbirinden farklılık gösterdiği için, bu kritere göre ayrı ayrı değerlendirme yapılmıştır. $\mathrm{Bu}$ makalede sadece çeltik üretimi yapan işletmelerin mekanizasyon düzeyi incelenmiştir. Çalışmada çeltik üretimi için, anket uygulanan köyler ve işletme sayıları Çizelge 1 'de verilmiştir.

Çizelge 1. Çeltik üretimi için anket uygulanan köyler ve işletme sayıları

\begin{tabular}{|c|c|c|c|c|c|c|c|}
\hline İlçe & Köy & Üretici Sayısı & Anket Sayısı & İlçe & Köy & $\begin{array}{c}\text { Üretici } \\
\text { Sayısı }\end{array}$ & $\begin{array}{l}\text { Anket } \\
\text { Sayısı }\end{array}$ \\
\hline \multirow{5}{*}{ Kargl } & Merkez & 105 & 12 & \multirow{5}{*}{ Osmancık } & Merkez & 364 & 39 \\
\hline & Halılar & 78 & 9 & & Kumbaba & 86 & 10 \\
\hline & Yeşilköy & 77 & 9 & & Güvercinlik & 59 & 7 \\
\hline & Dereköy & 70 & 8 & & Ardıç & 59 & 7 \\
\hline & Hacıhamza & 42 & 5 & & Girinoğlan & 44 & 4 \\
\hline Toplam & \multicolumn{4}{|c|}{ Üretici sayısı 948} & Anket sayısı & & \\
\hline
\end{tabular}

Araştırmanın tez aşamasında üreticilerin sosyoekonomik özellikleri ve işletme yapısına ilişkin genel bulgular toplam örnek hacmi üzerinden değerlendirilmiş olmasına karşın (363 anket), bu makalede çeltik üretimi yapan işletmeler ele alındığı için tüm değerlendirmeler çeltik üreticisi işletmeler dikkate alınarak (110 ankete göre) yapılmıştır. Bu amaçla çeltik üretimi yapan işletmelerin sosyoekonomik özellikleri, tarımsal alanların durumu, traktör ve tarım makineleri durumu, tarımsal uygulamalardaki toprak işleme, ekim-bakım gübreleme, sulama, ilaçlama, hasat ve harmanlama işlemleri ile depolamada kullanılan mekanizasyon kullanımları da anket sorularına göre belirlenerek değerlendirmeler yapılmış ve öneriler de bulunulmuştur. Çorum ili, Türkiye geneli ile beraber çeltik üretimi yapan işletmelerinin mekanizasyon düzeyinin belirlenmesinde yaygın olarak kullanılan kriterler, (birim traktöre düşen tarım alanı, birim tarım alanına düşen traktör gücü, 1000 ha tarım alanına düşen traktör sayısı, birim traktöre düşen makine ağırlığı, birim traktöre düşen makine sayısı esas alınmıştır (Kadayıfçllar ve ark., 1990, Ülger ve ark., 1996, Sabancı ve ark., 2003).

Bulgular ve Tartışma Çeltik üreticilerinin sosyo-ekonomik özellikleri Çeltik üretimi yapan işletmeler olarak ele alınan 110 anket verilerine göre, üreticilerin yaş ve eğitim durumları ile üreticilerin ekonomik ve sosyal güvence durumları Çizelge 2'de verilmiştir. Anket kapsamındaki çeltik üreticilerinin genel sosyoekonomik durumlarına bakıldığında, çeltik üreticilerinin \%59.10 oranında >50 yaş üzerinde olduğu, 40 yaş altı çiftçi oranı \%14.54'dür. Araştırmaya katılan işletmelerin eğitim durumlarına bakıldığında, üreticilerin \%2.73'ü hiç eğitim görmemiş, \%65.45'i ise ilkokul mezunu olup, üreticilerin çoğunluğunu oluşturmaktadır.

Üreticilerin \%30'u orta öğretim mezunu olup, üniversite mezunu \%1.82'sini oluşturmaktadır. İşletmelerin \%68.18'i geçimini yalnızca tarım ve hayvancılık yaparak sağlarken, \%31.82'si ise tarım ve hayvancılıkla uğraşmanın dışında ek gelir sağlayan çeşitli işlerle uğraşmaktadırlar.

\section{İşletmelerin arazi varlıkları}

Çeltik üretimi yapan işletmeler olarak ele alınan 110 anket verilerine göre, Çorum'daki çeltik tarımı yapan üreticilerin toplam arazi varlıkları 8519 dekar olup, arazilerin mülkiyet durumlarına bakıldığında, toplam arazi varlığının \%68.69'u işletmelerin kendi mülk arazilerinden oluşurken, toplam arazinin \%23.65'ini işletmelerin, aile yakınlarından veya diğer kişilerden kiralama yoluyla araziyi kullanmaktadır (Çizelge 3). 
Çizelge 2. Üreticilerin yaş, eğitim, mesleki durumları ile sosyal güvence durumları

\begin{tabular}{|c|c|c|c|c|c|c|c|c|c|c|c|}
\hline $\begin{array}{c}\text { Yaş } \\
\text { Dağılımı }\end{array}$ & Frekans & $\begin{array}{l}\text { Oran } \\
(\%)\end{array}$ & $\begin{array}{l}\text { Eğitim } \\
\text { Durumu }\end{array}$ & Frekans & $\begin{array}{l}\text { Oran } \\
(\%)\end{array}$ & $\begin{array}{l}\text { Mesleki } \\
\text { durumu }\end{array}$ & Frekans & $\begin{array}{l}\text { Oran } \\
(\%)\end{array}$ & $\begin{array}{l}\text { Sosyal } \\
\text { güvence } \\
\text { durumu }\end{array}$ & Frekans & $\begin{array}{c}\text { Oran } \\
(\%)\end{array}$ \\
\hline $20-30$ & 1 & 0.90 & $\begin{array}{c}\text { Okur } \\
\text { Yazar } \\
\text { Değil }\end{array}$ & 3 & 2.73 & Yok & 75 & 68.18 & Yok & 6 & 5.45 \\
\hline $31-40$ & 15 & 13.64 & İlkokul & 72 & 65.45 & Emekli & 19 & 17.28 & $\begin{array}{c}\text { SSK/Tarım } \\
\text { Sigortası }\end{array}$ & 11 & 10.0 \\
\hline $41-50$ & 29 & 26.36 & Ortaokul & 20 & 18.18 & Ticaret & 6 & 5.45 & $\begin{array}{l}\text { Tarım Bağ- } \\
\text { Kur }\end{array}$ & 45 & 40.91 \\
\hline $51-60$ & 38 & 34.55 & Lise & 13 & 11.82 & Muhtar & 2 & 1.82 & Bağ-Kur & 42 & 38.18 \\
\hline \multirow[t]{2}{*}{$>61$} & \multirow[t]{2}{*}{27} & \multirow[t]{2}{*}{24.55} & \multirow[t]{2}{*}{ Üniversite } & \multirow[t]{2}{*}{2} & \multirow[t]{2}{*}{1.82} & Memur & 2 & 1.82 & $\begin{array}{l}\text { Emekli } \\
\text { Sandığı }\end{array}$ & 1 & 0.91 \\
\hline & & & & & & Diğer & 6 & 5.45 & Diğer & 5 & 4.55 \\
\hline Toplam & 110 & 100 & Toplam & 110 & 100 & Toplam & 110 & 100 & Toplam & 110 & 100 \\
\hline
\end{tabular}

Çizelge 3. İşletmelerin arazi mülkiyet ile arazi kullanım durumları

\begin{tabular}{|c|c|c|c|c|c|c|c|c|}
\hline \multirow{3}{*}{$\begin{array}{c}\text { Arazi } \\
\text { durumu }\end{array}$} & \multicolumn{6}{|c|}{ Mülkiyet durumu (da) } & \multirow{3}{*}{$\begin{array}{c}\text { Toplam } \\
\text { alan } \\
\text { (da) }\end{array}$} & \multirow{3}{*}{$\begin{array}{c}\text { İşletme } \\
\text { başına } \\
\text { ortalama } \\
\text { (da) }\end{array}$} \\
\hline & \multicolumn{2}{|c|}{ Kendisine ait } & \multicolumn{2}{|c|}{ Kiralama } & \multicolumn{2}{|c|}{ Ortak } & & \\
\hline & Toplam & Ortalama $(*)$ & Toplam & Ortalama(*) & Toplam & Ortalama(*) & & \\
\hline Sulu & 4790 & 56.22 & 1851 & 21.72 & 563 & 6.61 & 7204 & 84.55 \\
\hline Kuru & 879 & 10.32 & 126 & 1.48 & 72 & 0.84 & 1077 & 12.64 \\
\hline Nadas & 183 & 2.15 & 38 & 0.46 & 17 & 0.20 & 238 & 2.81 \\
\hline Toplam & 5852 & 68.69 & 2015 & 23.65 & 652 & 7.65 & 8519 & 100.00 \\
\hline
\end{tabular}

* İşletme başına düşen arazi

Çizelge 4. Çeltik üretimi yapan işletmelerin toplam tarımsal alanların dağılımı, üretim deseni ve dağılımı ile çeltik üretim alanları

\begin{tabular}{|c|c|c|c|c|c|c|c|c|c|c|}
\hline $\begin{array}{c}\text { İşletme } \\
\text { büyüklüğü (da) }\end{array}$ & Frekans & $\begin{array}{l}\text { Oran } \\
(\%)\end{array}$ & $\begin{array}{l}\text { Ortalama } \\
\text { ișletme } \\
\text { büyüklüğü } \\
\text { (da) }\end{array}$ & Ürün adı & $\begin{array}{l}\text { Ekim } \\
\text { alanı } \\
\text { (da) }\end{array}$ & $\begin{array}{l}\text { Oran } \\
(\%)\end{array}$ & $\begin{array}{l}\text { Çeltik ekili } \\
\text { alan } \\
\text { büyüklüğü } \\
\text { (da) }\end{array}$ & Frekans & $\begin{array}{c}\text { Oran } \\
(\%)\end{array}$ & $\begin{array}{c}\text { Ortalama } \\
\text { alan } \\
\text { (da) }\end{array}$ \\
\hline $1-50$ & 59 & 53.64 & 35 & Çeltik & 5643 & 68.14 & $1-5$ & 62 & 56.36 & 4.05 \\
\hline $51-100$ & 41 & 37.26 & 75 & Buğday & 1959 & 23.66 & $6-10$ & 34 & 30.91 & 7.29 \\
\hline $101-200$ & 4 & 3.64 & 138 & Arpa & 457 & 5.52 & $11-20$ & 11 & 10.00 & 14.00 \\
\hline $201-300$ & 2 & 1.82 & 233 & Diğer & 222 & 2.68 & $21-30$ & 3 & 2.73 & 27.00 \\
\hline $301-400$ & 1 & 0.91 & 370 & & & & $31-40$ & - & - & - \\
\hline $401-500$ & 2 & 1.82 & 495 & & & & $41-50$ & - & - & - \\
\hline \multirow[t]{2}{*}{$>500$} & 1 & 0.91 & 1000 & & & & 51-100 & - & - & - \\
\hline & & & & & & & $>100$ & - & - & - \\
\hline Toplam & 110 & 100 & 77.0 & Toplam & 8281 & 100 & Toplam & 110 & 100 & 6.67 \\
\hline
\end{tabular}

Çizelge 3'ten görüleceği gibi, işletmelerin toplam arazi varlıklarının \%12.64'ü kuru arazilerden oluşmakta, \%84.55'i sulu ve taban arazilerden oluşurken, \%2.81'i ise nadasa birakılan arazidir. Ortalama işletme büyüklüğü ise 77.0 dekardır. Çizelge 4'te, çeltik üretimi yapan işletmelerin toplam tarımsal alanların dağılımı, üretim deseni ve dağılımı ile çeltik üretim alanları verilmiştir.

Çizelge 4'ten görüleceği gibi, tarım işletmelerinin toplam tarım alanları incelendiğinde, \%53.64'inin 1 ile 50 dekar arasında araziye sahip olduğu, \%90.90'ı ise 1 ile 100 dekar arasında araziye sahip oldukları belirlenmiştir. Ankete dahil işletmelerdeki 100 dekardan daha büyük arazisi olan işletmelerin oranı
\%9.10 iken, 500 dekardan daha büyük arazisi olan işletmelerin sadece \%0.91'ini kapsamakta olup, işletmelerin genel olarak küçük ölçekli işletmelerde tarımsal üretimlerini sürdürmektedir. Çeltik üreticilerinin ekim alanlarına bakıldığında, ekili alanın \%23.66'sını buğday, \%5.52'sini ise arpa oluşturmaktadır. İşletmelerin toplam çeltik ekim alanı 5643 dekardır. İşletmelerin sahip oldukları arazilerde ekili alanın \%68.14'ünde çeltik yetiştirilmektedir. İșletmelerin \%97.27'si, 1-20 dekar arasında büyüklüğe sahip alanda çeltik tarımı yapmaktadır.

\section{Çeltik tarımı yapan işletmelerin mekanizasyonuna ilişkin bulgular}




\section{İşletmelerin traktör varlıkları}

Araştırma kapsamında incelenen 110 işletmenin \%93.64'ünde traktör bulunurken, \%6.36'sında traktör olmadığı tespit edilmiştir. İşletmelerde, 2 traktöre sahip olanlar \%1.82 ve 3 tane traktörü olanlar ise \%1.82 oranında bulunmuștur. İşletme başına düşen ortalama traktör sayısı ise 0.94 olarak bulunmuştur. Çizelge 5'de ise işletmelerde mevcut olan traktörlerin markaları verilmiştir. Traktör sahibi işletmelerin dokuz değişik marka traktöre sahip olduğu görülmekte olup, marka kullanımında ilk sırada \%34.58 ile New Holland, ikinci sırasında \%19.63 ile Massey Ferguson olduğu belirlenmiştir. Anket sonuçlarından işletme sahiplerinin New
Holland ve Massey Ferguson marka traktörleri \%53.21 oranında daha fazla tercih ettikleri görülmektedir.

Bu iki traktör markası, Türkiye'de en fazla traktör üretimi olan markalar olup, bu durum çiftçiler için önemli bir tercih nedeni olabilmektedir. Ayrıca Sağlam ve Çevik (2012)'e göre, traktör satın alınırken, üreticilerin davranışına en fazla etkili olan faktörlerin traktör için güç büyüklüğü yanında ayrıca, yedek parça bulma kolaylığı ve traktör fiyatının olduğu açıklanmakta olup, bu seçim faktörlerinin de çiftçilerin traktör alımında etkili olduğu söylenebilir.

Çizelge 5. Çeltik üretimi yapan işletmelerdeki traktör markaları

\begin{tabular}{ccc|ccc}
\hline Traktör markası & Sayısı (adet) & Oranı (\%) & Traktör markası & Sayısı (adet) \\
\hline New Holland & 37 & 34.58 & Tümosan & 4 & Oranı (\%) \\
Massey Ferguson & 21 & 19.63 & Ford & 2.74 & 1.87 \\
Erkunt & 19 & 17.76 & Deutz & 1 & 0.93 \\
Fiat & 16 & 14.95 & Case & 0.93 \\
John Deere & 6 & 5.61 & & \\
\hline
\end{tabular}

Çizelge 6. Çeltik üretimi yapan işletmelerdeki traktörlerin yaş durumları ve güç dağılımları

\begin{tabular}{|c|c|c|c|c|c|c|}
\hline $\begin{array}{l}\text { Traktörlerin yaş } \\
\text { dağılımları }\end{array}$ & $\begin{array}{l}\text { Traktör sayısı } \\
\text { (adet) }\end{array}$ & $\begin{array}{c}\text { Oranı } \\
(\%)\end{array}$ & $\begin{array}{c}\text { Traktörlerin güç } \\
\text { grupları } \\
(\mathrm{BG})^{*}\end{array}$ & Sinıflandırma* & $\begin{array}{c}\text { Traktör sayısı } \\
\text { (Adet) }\end{array}$ & $\begin{array}{c}\text { Tüm traktörler } \\
\text { içindeki } \\
\text { oranı }(\%)\end{array}$ \\
\hline $1-5$ & 37 & 34.58 & $11-22$ & Küçük & - & - \\
\hline $6-10$ & 23 & 21.50 & $23-33$ & Küçük-orta & - & - \\
\hline $11-15$ & 11 & 10.28 & $34-45$ & Orta & 8 & 7.48 \\
\hline $16-20$ & 9 & 8.41 & $46-60$ & Orta-büyük & 52 & 48.60 \\
\hline $21-25$ & 12 & 11.21 & $61-75$ & Büyük & 35 & 32.71 \\
\hline$>25$ & 15 & 14.02 & $>75$ & Çok büyük & 12 & 11.21 \\
\hline Toplam & 107 & 100 & Toplam & & 107 & 100 \\
\hline
\end{tabular}

* Culpin (1975), Yildız (2002)

Çizelge 6'da işletmelerdeki traktörlerin yaş düzeyi ile güçlerine göre dağılımları verilmiştir. Anket uygulanan 110 işletmenin \%97.27'sinde traktör yaş ortalaması 11.89 yıldır. Traktör yaş grupları incelendiği zaman, Türkiye şartlarında kabul edilen 24 yıl mekanik kullanma ömürleri açısından (Ulusoy ve ark., 2010), anket yapılan işletmelerdeki traktörlerin yaklaşık \%85'inin bu sınıra ulaşmadıkları görülmektedir.

Fakat traktörlerin \%14.02'sinin mekanik olarak ömrünü tamamladığı, ancak maddi olanaklar nedeniyle işletme sahipleri tarafından yenisiyle değiştirilemedikleri anlaşılmaktadır. Yapılan araştırmada en eski traktörün 1967 model olduğu tespit edilmiş ve 20 yaş üzerindeki traktör sayısının ise \%25.23 olduğu görülmüştür. İşletmelerde 11-33 BG arasında güce sahip olan traktörlerin bulunmadığı görülmektedir. Araştırma kapsamında incelenen işletmelerde, motor gücü en küçük olan traktörün $34.85 \mathrm{BG}$ (26 kW) güce, motor gücü en büyük traktörün ise $110 \mathrm{BG}(82 \mathrm{~kW})$ güce sahip olduğu gözlenmiştir.

Anket yapılan işletmelerdeki traktörlerin ortalama motor gücünün ise $45.11 \mathrm{~kW}$ olduğu tespit edilmiştir. İncelenen işletmelerle Türkiye ortalaması kıyaslandığında; Türkiye traktör parkının ortalama motor gücünün $43 \mathrm{~kW}$ olduğuna göre anket uygulanan işletmelerin sahip oldukları ortalama traktör motor gücünün Türkiye ortalamasının kısmen üzerinde olduğu söylenebilir (Sabancı ve ark., 2003; Evcim, 2008). Traktörü olan 107 işletmede, traktörlerin genelde (\%81.31) orta-büyük ve büyük diyebileceğimiz 46-75 BG arasında olduğu görülmektedir. İşletmelerin \%48.60'ında traktör motor gücünün 46-60 BG aralığındaki orta-büyük güç grubu aralığında olduğu görülmektedir. Çorum 
ili çeltik üretimi yapan işletmelerin traktör güçlerinde dikkat çeken önemli bir nokta; orta büyük ve büyük güç grubunda yer alan traktörlerin kullanılmasıdır. Zira Türkiye genelinde de, traktör güç gruplarında daha yüksek güç grubuna sahip traktörlerde dikkate değer oranda artışlar söz konusudur (Altuntaş, 2016). Çeltik üretimi yapan ankete dahil işletmelerde kullanılan traktörlerin ortalama motor gücünün, Türkiye ortalamasının üzerinde olmasına rağmen, yörede yıllık ortalama traktör kullanım süresinin ancak Türkiye ortalamasının alt sınırında olduğunu ve dolayısıyla atıl kapasitenin mevcut olduğu görülmektedir. Bu sürenin gelișmiş ülkelerde ise yaklaşık 700-1000 saat yll $^{-1}$ olduğu Yıldız (2002); Sabancı ve ark. (2003) tarafindan ifade edilmektedir. $\mathrm{Bu}$ rakamlara bakıldığında, çeltik üretimi yapılan yörede, atıl traktör gücünün söz konusu olduğu söylenebilir.

\section{İşletmelerin sahip oldukları tarım alet ve makineler}

Tarımsal üretimde traktörün etkin ve verimli şekilde kullanılmasını sağlayan, traktörle kullanılan tarım alet ve makineleridir.

$\mathrm{Bu}$ nedenle traktör başına düşen alet makine sayısı önemli bir kriterdir. Anket uygulanan işletmelerin sahip oldukları alet ve makineler, Çizelge 7'de verilmiştir.

Çizelge 7. Çeltik üretimi yapan işletmelerin sahip oldukları tarım alet ve makineler

\begin{tabular}{|c|c|c|c|c|c|}
\hline \multicolumn{2}{|c|}{ Tarım alet-makinesi } & $\begin{array}{c}\text { Alet } \\
\text { makine } \\
\text { sayısı }\end{array}$ & $\begin{array}{c}\text { Toplam işletme } \\
\text { sayısına oranı } \\
(\%)\end{array}$ & $\begin{array}{c}\text { Traktör başına } \\
\text { düsen alet makine } \\
\text { oranı }\end{array}$ & $\begin{array}{l}\text { İşletme başına } \\
\text { düsen alet } \\
\text { makine } \\
\text { oranı }\end{array}$ \\
\hline \multirow{12}{*}{$\begin{array}{l}\text { Toprak işleme alet ve } \\
\text { makineleri }\end{array}$} & Kültüvatör (kazayağı) & 104 & 94.55 & 0.97 & 0.94 \\
\hline & Kulaklı pulluk & 103 & 93.64 & 0.96 & 0.94 \\
\hline & Merdane & 11 & 10.00 & 0.10 & 0.10 \\
\hline & Dișli tırmık & 8 & 7.27 & 0.07 & 0.07 \\
\hline & Diskli tırmık (diskaro) & 6 & 5.45 & 0.06 & 0.05 \\
\hline & Dipkazan & 7 & 6.36 & 0.065 & 0.06 \\
\hline & Kombikürüm (karma tırmık) & 3 & 2.73 & 0.03 & 0.03 \\
\hline & Toprak frezesi (rotovatör) & 11 & 10.00 & 0.10 & 0.10 \\
\hline & Tesviye küreği & 55 & 50.00 & 0.51 & 0.50 \\
\hline & Çizel & 1 & 0.91 & 0.009 & 0.009 \\
\hline & Diskli pulluk & 3 & 2.73 & 0.03 & 0.03 \\
\hline & Lazerli tesviye aleti & 2 & 1.82 & 0.02 & 0.02 \\
\hline \multirow{4}{*}{$\begin{array}{c}\text { Ekim, dikim, } \\
\text { gübreleme ve } \\
\text { çapalama makineleri }\end{array}$} & Kom. hububat ekim makinesi & 18 & 16.36 & 0.17 & 0.16 \\
\hline & Üniversal ekim makinesi & 1 & 0.91 & 0.009 & 0.009 \\
\hline & Kimyevi gübre dağ.makinesi & 25 & 22.73 & 0.23 & 0.23 \\
\hline & Pnömatik ekim makinesi & 3 & 2.73 & 0.03 & 0.03 \\
\hline \multirow{7}{*}{$\begin{array}{c}\text { Hasat-harman } \\
\text { makineleri }\end{array}$} & Sap döver harman makinesi & 14 & 12.73 & 0.13 & 0.13 \\
\hline & Ot tırmığ & 1 & 0.91 & 0.009 & 0.009 \\
\hline & Orak makinesi & 1 & 0.91 & 0.009 & 0.009 \\
\hline & Balya makinesi & 3 & 2.73 & 0.03 & 0.03 \\
\hline & Çayır biçme makinesi & 2 & 1.82 & 0.02 & 0.02 \\
\hline & Biçerdöver & 3 & 2.73 & & 0.03 \\
\hline & Pancar sökme makinesi & 2 & 1.82 & 0.02 & 0.02 \\
\hline \multirow{3}{*}{$\begin{array}{l}\text { Tarımsal mücadele } \\
\text { makineleri }\end{array}$} & Traktör pülverizatörü & 28 & 25.45 & 0.26 & 0.25 \\
\hline & Sirt pülverizatörü & 62 & 56.36 & - & 0.56 \\
\hline & Atomizör (sırt tipi) & 25 & 22.73 & - & 0.23 \\
\hline \multirow{5}{*}{$\begin{array}{l}\text { Diğer bazı alet ve } \\
\text { makineler }\end{array}$} & Traktör & 107 & 97.27 & - & 0.97 \\
\hline & Tarım arabası & 101 & 91.82 & 0.94 & 0.92 \\
\hline & Su tankeri & 3 & 2.73 & 0.03 & 0.03 \\
\hline & Yem hazırlama makinesi & 5 & 4.55 & 0.05 & 0.04 \\
\hline & Kepçe (tarımda kullanılan) & 2 & 1.82 & 0.02 & 0.02 \\
\hline
\end{tabular}

İșletmelerin sahip oldukları tarım alet ve makineleri 5 gruba ayrılmıș, toprak işleme alet ve makineleri, ekim, dikim, gübreleme ve çapalama makineleri, hasat ve harman makineleri, tarımsal mücadele makineleri ile diğer bazı alet ve makineleri olarak gruplandırılmıștır. İșletmelerin genel olarak sahip oldukları alet ve makine varlıkları incelendiğinde kültüvatör, kulaklı pulluk ve tarım arabası toplam alet-makine sayısının \%52'sini teșkil ettiği görülmektedir. Toprak işleme alet ve makineleri grubunda yer alan tarım alet ve makinelerin bașında \%96.36 ile en çok karşılaşılan alet pulluk gelmektedir. Çeltik üretimi yapan ankete dahil işletmelerde tarımsal faaliyette bulunan traktör 
sahibi üreticilerin genellikle kulaklı pulluk (\%97.17) tercih ettikleri görülmektedir. Pulluk gövdesi bakımından 3 gövdeli pulluk yoğunlukta olup 2-5 arasında gövdeye sahip kulaklı pulluklarda işletmelerde bulunmaktadır. Diskli pulluk işletmelerde yalnızca \%2.73 oranında bulunmakta olup kullanımı oldukça düşük düzeydedir. Ayrıca işletmelerde sadece \%0.91 oranında korumalı toprak işlemede kullanılan çizel pulluk ekipmanı da bulunmaktadır. Pulluktan sonra en çok kullanılan toprak işleme aleti olarak işletmelerin \%94.55'inde kültüvatör bulunmaktadır. Hemen hemen her traktöre bir adet kültüvatör (0.97) düşmektedir. Bölgede çeltik tarımının dışında diğer tarla bitkilerinin mekanizasyonun da sıkça kullanıldığı bir tarım aletidir. İșletmelerde bulunan kültüvatörün tümü kazayağı tipindedir. Ayak sayıları bakımından daha çok 11 ayaklı mevcut olup, 9-13 arasında ayağa sahip kazayağı tipi kültüvatörler de bulunmaktadır. Kültüvatör, sonbahar sürümü yapılmış tarlalarda ilkbaharda toprak hazırlı̆̆ında kullanılmaktadır. İşletmelerde pulluk ve kültüvatörden sonra en çok bulunan toprak işleme aleti \%51.82 ile tesviye aletleri gelmektedir. Çeltik tarımında tesviye çok önemli bir yere sahiptir. İșletme sahiplerinde tesviye aleti olarak daha çok tesviye küreği $\% 50$ oranında bulunmakta olup \%1.82 oranında işletmelerde daha hassas olan lazerli tesviye aleti bulunmaktadır. İşletmelerin \%15.45'inde tırmık bulunmaktadır. Bunlardan da sayı olarak \%7.27 oranında işletmelerde dişli tırmık, \%5.45 oranında işletmelerde diskli tırmık (diskaro) \%2.73 oranında işletmelerde karma tırmık olarak adlandırılan kombikürüm bulunmaktadır. Toprak işlemede ikincil toprak işleme aleti olarak kullanılan tırmıklardan genelde dişli tırmık ve diskli tırmık (diskaro) tercih edildiği görülmektedir. Toprak işleme alet ve makineleri grubunda yer alan bir diğer alet ise merdanelerdir. Çeltik tarımında her ne kadar merdaneler kullanılmasa da diğer bitkilerin ekiminde tohum ekimi yapıldıktan sonra iyi bir tohum toprak temasını sağlamak ve toprak nemini muhafaza ederek yüksek bir çimlenme sağlamak için merdanelere ihtiyaç duyulmaktadır. Düz, dalgalı ve dişli tiplerinde olmak üzere toplamda işletmelerin $\% 10.00$ 'unda merdane bulunmaktadır. Toprak işleme alet ve makineleri grubunda yer alan diğer alet ve makinelere bakıldığında \%10.00'unda toprak frezesi ve \%6.36'sında da dipkazan bulunmaktadır.

Ekim, dikim, gübreleme ve çapalama makineleri grubunda en çok bulunan alet ve makineler olarak santrifüj gübre dağıtma makineleri gelmektedir. Çeltik tarımında kimyevi gübre dağıtma makineleri genellikle ekim işleminde kullanılmaktadır. Uygulanan ankette 110 üreticiden \% 22.73'ünde santrifüj gübre dağıtma makinesi mevcuttur. $\mathrm{Bu}$ grupta yer alan bir diğer tarım alet ve makineleri olarak işletmelerin \%20.00'sinde bulunan ekim makineleri gelmektedir. Bunun da \%85.71'i kombine hububat ekim makinesi, bir adet yalnızca tohum eken üniversal ekim makinesi, \%2.73'ü ise pnömatik ekim makinesidir. Anket yapılan bölgede çoğunlukla çeltik tarımının yapılması ve çeltik ekiminin de genellikle elle, sırt tipi atomizör ve kimyevi gübre dağıtma makineleri ile yapıldığından bölge çiftçilerinde ekim makineleri fazla bulunmamaktadır. Tarımsal mücadele makineleri grubunda yer alan ve işletmelerde $\% 81.82$ oranında pülverizatörler gelmektedir. 90 adet olan bu pülverizatörün çoğunluğunu 62 adet ile sırt pülverizatörleri oluştururken 28'ini kuyruk mili tahrikli tarla pülverizatörü oluşturmaktadır. Pülverizatörler çeltik tarımında daha çok yabancı ot mücadelesi ile sıvı yaprak gübrelemesinde kullanılmaktadır. Kapasite olarak sırt pülverizatörleri 15-25 litre, tarla pülverizatörleri ise 300-600 litre hacime sahiptir. Bu grupta yer alan diğer bir tarımsal mücadele makinesi olan atömizör ise 25 işletmede bulunmaktadır. Atömizörler motorlu sirt tipinde olup 20-25 litrelik bir hacme sahip olup, ilaçlamanın dışında içine yerleştirilen bir aparat sayesinde gübreleme ve ekim işleminde de son yıllarda yaygın olarak kullanılmaktadır.

Hasat ve harman makineleri grubunda ise işletmelerde \%12.73 oranı ile en çok miktarda bulunan makine, sap döver harman makinesidir. Biçerdöver kullanımının artışına bağlı olarak, bazı sap döver harman makinelerinin atıl durumda oldukları gözlemlenmiştir. Mevcut kullanılanları ise, biçerdöverle hasatı mümkün olmayan arazilerde tırpan ya da kanatlı orak makinesiyle yapılan hasadın harman işleminde kullanılmaktadır. Hasat ve harman makineleri grubunda yer alan işletmelerde bulunan diğer alet ve makinelere bakıldığında; işletmelerin \%2.73'ünde biçerdöver ve balya makinesi, \%1.82'inde pancar sökme makinesi ve çayır biçme makinesi, birer işletmede ise ot tırmığı ve kanatlı orak makinesi bulunmaktadır. Bunun dışında işletmelerde diğer bazı alet ve makine grubunda ise traktör, tarım arabası, yem hazırlama makinesi, su tankeri ve tarımda kullanılan kepçesi bulunmaktadır. 110 işletmenin 103'ünde toplamda 
107 traktör bulunurken, 101 adet ile tarım arabası bulunmakta olup, birim traktör başına 0.94 tarım arabası düştüğü gözlenmiştir. 5 işletmede yem hazırlama makinesi, 3 işletmede su tankeri ve 2 işletme sahibinde de tarımda kullanılan kepçe bulunmaktadır. Genel bir değerlendirme yapıldığında, çeltik üretimi yapılan işletmelerde; tarım arabası, pulluk ve kültüvatör kullanımında bir yoğunlaşma söz konusudur. Buna karşın çeltik tarımında ekim-bakım, tarımsal mücadele ile tesviye ișlemlerinde kullanılan alet ve makinelere ihtiyaç duyulduğu görülmektedir.

Anket yapılan işletmelerde traktör bașına düșen aletmakine sayısı 4.90 adet olup, Türkiye ortalaması olan 4.79 adet değerine göre daha yüksek değerdedir.. Ancak bașta sap döver harman makinesi olmak üzere bazı alet ve makinelerin atıl durumda oldukları görülmekte olup, tarım alet-makine parkının yıl içerisinde verimli kullanılamadığı gözlenmiştir. Nitekim üretimin her aşamasında yeterli alet ve makine mevcut olmadığı, yörede doğal șartlar, tarımsal üretimin çeșitliliği ve sürenin kısıtlı olmasından dolayı traktör ve diğer alet ve makinelerin yıllık çalışma süreleri düşmekte ve özellikle traktör kullanımının ekonomik olmaktan çıkmasına sebep olmaktadır. Yaoming (2003), Çin'de çeltik üretim mekanizasyonu konusunda ekim ve dikim uygulamalarında makine kullanımının yetersiz olduğunu, ekim işleminin doğrudan kuruya ekim ile beraber ıslatılmış çeltiğin ekimine yönelik makinelerin geliştirilip yoğun olarak kullanılmaya başladığını, doğrudan ekimin yanı sıra fideden dikim yönteminin de giderek yaygınlaştığını, son yıllarda hasat için yolucu başlıklı olan biçerdöverin çeltik için daha uygun olduğunu açıklamıştır. Bu çalışmada, çeltik üretiminde kuru ve sulu olmak her iki ekim yönteminde uygulandığl, çoğunlukla elle ekimin gerçekleștirildiği, bölgede doğrudan ekim ve fideden dikim yönteminin ise uygulanmadığı görülmüştür.

\section{Çeltik üretimi yapan işletmelerin tarımsal} mekanizasyon düzeyine ait sonuçlar

Anket yapılan Osmancık ve Kargı ilçelerindeki işletmelerdeki tarımsal mekanizasyon düzeyini belirten, birim alana düşen traktör gücü $(\mathrm{kW}$ ha-1), 1000 hektar alana düşen traktör sayısı (traktör 1000 ha $^{-1}$ ), birim traktöre düșen işlenen alan (ha traktör ${ }^{-1}$ ) ve birim traktöre düşen alet-makine sayısı (adet traktör-1) kriterleri, Çizelge 8'de verilmiștir.

Çizelge 8. Çeltik üretimi yapan işletmelerin mekanizasyon düzeyleri

\begin{tabular}{cccccc}
\hline & & & \multicolumn{3}{c}{ Tarımsal mekanizasyon düzeyi } \\
\hline & $\begin{array}{c}\text { İşlenen alan } \\
\text { (ha) }\end{array}$ & $\begin{array}{c}\text { Traktör sayısı } \\
\text { (adet) }\end{array}$ & kW ha ${ }^{-1}$ & traktör 1000ha-1 & ha traktör-1 $^{\text {adet traktör-1 }^{-1}}$ \\
\hline Çeltik üreten işletmeler & 851.9 & 107 & 5.4 & 125.6 & 7.96 \\
Çorum & 352471 & 28111 & 3.43 & 79.75 & 4.90 \\
Türkiye & 15574639 & 1273531 & 3.52 & 81.77 & 4.99 \\
\hline
\end{tabular}

Araștırma bölgesindeki bulgular bizzat anket sonuçlarına göre tespit edilmiştir. Çizelge 8 incelendiğinde anket kapsamındaki Osmancık ve Kargı ilçelerindeki işletmelerde birim alana düșen traktör gücünün, Türkiye ve Çorum ortalamasından daha yüksek olduğu ve yaklaşık 1.5 katı değerinde olduğu görülmüştür. Zira, Türkiye ortalaması 3.52 $\mathrm{kW} \mathrm{ha}^{-1}$, Çorum genelinde $3.43 \mathrm{~kW} \mathrm{ha}^{-1}$ iken anket

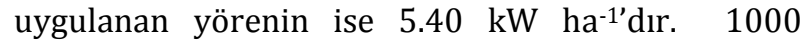
hektara düșen traktör sayısı Türkiye ortalaması 81.77 traktör ve Çorum ili için ise 79.75 traktör iken anket uygulanan işletmelerde 1000 hektara düşen traktör sayısı 125.60 adet olup, bu değerin Türkiye ortalaması ve Çorum ili genelinin 1.5 katından daha yüksek olduğu anlaşılmaktadır. Birim traktöre düşen tarımsal alana bakıldığında ise, Çorum ili 12.54 ha traktör-1, Türkiye ortalaması ise 12.23 ha traktör-1 değerinde olup, anket yapılan işletmelerde 7.96 hektar olup, anket değeri, Türkiye ortalamasına (12.23) göre oldukça az olduğu görülmektedir. Anket uygulanan işletmelerde bu değerin birim tarım alanı başına göre daha düşük olması istenmektedir. Bu duruma neden ise, yöredeki üreticilerin sahip oldukları traktör sayısının, Türkiye ortalamasına göre fazla oluşundan kaynaklanmaktadır. Çeltik üreticisi işletmelerin mekanizasyon seviyesinin bu anlamda Türkiye ortalamasından daha iyi olduğu söylenebilir.

Yazıcı (2006), Erzurum ili Pasinler Ovası'nda şeker pancarı üretimi yapan işletmelerin mekanizasyon durumu için, işletmelerin arazi büyüklüğünün ortalama 10.45 ha, traktör motor gücünün $43.27 \mathrm{~kW}$, birim alana düşen traktör gücünün $3.87 \mathrm{~kW}, 1000$ ha birim alanına düsen traktör sayısının 89.51 
traktör, bir traktöre düșen birim işlenen alanın 11.17 ha, traktör başına düşen ekipman sayısının 5.10 adet olduğunu açıklamışlardır. Erzurum ili Pasinler ovasındaki işletmelerin mekanizasyon düzeylerinin Türkiye ortalamasından daha yüksek durumda olduğunu, traktör başına düşen alet-makine sayısının Türkiye ortalamasından \%23 daha fazla olmasına karşın, makinelerin tüm tarımsal işlemlere uygun bir şekilde dağılım göstermediğini ifade etmiştir. Bu çalışmada çeltik üretiminde kullanılan traktör motor gücünün $45.11 \mathrm{~kW}$, birim alana düșen traktör gücünün $5.4 \mathrm{~kW} \mathrm{ha}^{-1}, 1000$ ha birim alanına düşen traktör sayısının 125.6 traktör değerinde olduğu, dolayısıyla Erzurum ili Pasinler Ovasındaki şeker pancarı üretimindeki verilen değerlere göre daha yüksek değerlere ulaşıldığı söylenebilir. Bir traktöre düşen birim işlenen alanın 7.96 ve traktör başına düșen ekipman sayısının 4.9 adet değeriyle ise, Erzurum ili Pasinler Ovasındaki şeker pancarı üretiminde kullanılan değerlerden daha düşük olduğu gözlenmiştir.

Çiçek ve Çelen (2000), anket yöntemiyle, Meriç havzasındaki çeltik üretimi yapan tarımsal işletmelerin mekanizasyon durumunun belirledikleri çalışmalarında işletmelerin mekanizasyon durumunun, Trakya Bölgesi ve Türkiye ortalamasından daha yüksek olduğunu, fakat çeltik tarımında makineleşmenin tamamen sağlanamadığını ifade ederek makineleşmenin tamamlanmasıyla ürün veriminde önemli miktarlarda artışların sağlanabileceğini ifade etmişlerdir. Yapılan bu çalışmada da çeltik tarımında bașta ekim olmak üzere gübreleme gibi tarımsal uygulamalarda mekanizasyonun yeterince kullanılmadığı, ancak, toprak işleme aletleri açısından yeterli bir kullanımın olduğu görülmüştür. Traktör başına düşen alet makine sayısına bakıldığı zaman bu değerinde Türkiye ortalamasından daha yüksek olduğu görülmüștür, ancak, yine de, anket yapılan Osmancık ve Kargı ilçelerindeki işletmelerin alet makine varlığı bakımından mekanizasyon zincirini tam anlamıyla tamamlayamadığını ifade etmek gerekmektedir. Yöre üreticisinde tarım alet ve makineleri olarak, tarım arabası, pulluk ve kültüvatör açısından bir yoğunluk söz konusudur. Anket yapılan işletmelerin çoğunda (\%93.64), traktör olduğu halde ekim, bakım, tarımsal mücadele ve toprak tesviye işlemlerini gerçekleştirecek yeterli düzeyde alet ve makinelerin olmadı̆̆ dikkat çekmiştir. Nitekim araştırma kapsamında incelenen işletmelerin ekim ve gübreleme işlemlerini çoğunlukla elle yapmaları, \%48.18'inde toprak tesviyesi aleti ve \%77.27'sinde gübre serpme makinesinin olmaması, bu işletmelerin çoğu bu işlemleri kiralama ile bazı kültürel işlemleri de elle yapmalarına neden olmaktadır. Ayrıca, traktörü yıl boyunca yükleyecek alet-makine olmayışı, traktörün yıl içerisinde düşük kapasite ile çalışmasına ve atıl kapasitenin ortaya çıkmasına sebep olmaktadır. Bu durum traktörün bir güç kaynağı olarak ne kadar verimli kullanılabildiği sorusunu akla getirmektedir. Zira, tarımda makineleşme denilince akla sadece traktöre sahip olmanın yeterli olmadığı, özellikle yeterli alet ve makinenin uygun planlama ile ve verimli bir şekilde kullanılması gerekmektedir.

\section{Çeltik üretiminde tarımsal işlemlerdeki mekanizasyon uygulamaları}

Toprak hazırlığı: Çeltik üretiminde tarımsal işlemlerdeki toprak işlemede en fazla tercih edilen alet-makine kombinasyonları, Çizelge 9'da verilmiştir.

Çizelge 9. Çeltik üretimi yapan işletmelerin toprak hazırlığına yönelik işlemlerdeki aletmakine kombinasyonları

\begin{tabular}{ccc}
\hline Alet makine kombinasyonları & Frekans & $\begin{array}{c}\text { Oran } \\
(\%)\end{array}$ \\
\hline Pulluk+kültüvatör+tırmık+ekim & 68 & 61.81 \\
Pulluk+kültüvatör+kültüvatör+ekim & 21 & 19.1 \\
Pulluk+kültüvatör+ kültüvatör+tırmık+ekim & 16 & 14.54 \\
Pulluk+rotovatör+ekim & 2 & 1.82 \\
Pulluk+pulluk+kültüvatör+tırmık+ekim & 2 & 1.82 \\
Pulluk+pulluk+kültüvatör+kültüvatör+ekim & 1 & 0.91 \\
\hline Toplam & 110 & 100 \\
\hline
\end{tabular}

Çeltik üretiminde hasat, Ekim ayının ortalarına kadar devam ettiğinden, toprak işleme için sonbahar sürümü çok az işletme (\%4.55) dışında, çoğu işletme sahibi ilkbahar aylarında Nisan ayı içerisinde toprak tavlı iken pullukla $(25-30 \mathrm{~cm})$ derin sürüm yapmaktadır. Bazı işletmelerde toprakta oluşan geçirimsiz (pulluk tabanı) tabakasını kırmak için pullukla sürümden önce dipkazanla toprak işlemesi yapmaktadırlar. Çorum bölgesinde çeltik için tohum yatağının hazırlanmasına, Nisan aylarında başlamakta, iklim durumuna bağlı olarak işletmeler tarafından bir veya iki kez olmak üzere kazayağı tipi kültüvatörle toprak kabartılıp ardından tırmık çekilmektedir. Daha sonra arazi tesviyesi yapılmaktadır. Arazi tesviyesini Kargı ilçesindeki işletmelerin hemen hemen hepsi tesviye işlemini mevcut çeltik arazileri için her yıl yaparken Osmancık ilçesindeki yetiştiricilerin ise yaklaşı \%30'u her yıl geriye kalan \%70 işletme sahibi ise, 
arazi tesviyesini ilk kez çeltik ekeceği arazi için uygulamaktadır. Arazi tesviyesi daha çok tesviye küreği ile yapılırken yaklaşık \%15’e yakın işletme sahibi de lazerli tesviye aleti ile tesviye yapmaktadır. Lazerli tesviye aletini kullanan işletmeler verimde yaklaşık \%20-30 verim artışı olduklarını beyan etmişlerdir. Çorum ilinde çeltik tarımı uzun yıllardır yapıldığından toprak işlemeden önce kanalların yapımı, tavaların yapılması ile seddelerin yapılması gibi hazırlık işlemleri mevcut çeltik arazileri için söz konusu olmayıp, ilk kez çeltik yetiştiriciliği yapılacak araziler için sözkonusudur. Bunun için de öncelikle tarlanın en yüksek yerinden ana sulama kanalı, en alçak yerinden ise ana boşaltma kanalları yapılmaktadır. Daha sonra arazi tesviyesi yapıldıktan su dağıtma ve boşaltma kanalları yapılmakta, bunu tavaların yapılması takip etmektedir. Yörede tavaların ortalama büyüklükleri 1-3 dekardır. Tavaları birbirinden ayırmak için yapılan sedde ve tirlerin yapımı ise bel ve kürekle yapıldığı gibi tesviye bıçağı ile de yapılmaktadır. Seddelerin yüksekliği ise $45-75 \mathrm{~cm}$ arasında değișmektedir.

Ekim: Çeltik ekimi Çorum ilinde iklim şartlarına bağlı olarak, Mayıs ayının başından başlayıp sonuna kadar devam etmektedir. Çeltikte 'sulu ekim' ve 'kuru ekim' olmak üzere iki türlü ekim yöntemi uygulanmaktadır. Ankete dahil işletmelerin yaklaşık \%80-85'i sulu ekim, \%15-20'si ise kuru ekim yapmaktadır. Sulu ekimden kastedilen arazi su ile göllendirildikten sonra ekim işleminin gerçekleştirilmesi, kuru ekimde ise önce ekimin yapılması ardından araziye su verilmesi işlemidir. Ekim işlemi farklı yöntemlerle gerçekleştirilmektedir. Geçmiş yıllarda çoğu üretici elle ekim yaparken son yıllarda sırt pompasına gübre atma aparatının yerleștirilmesiyle yeni ve pratik bir yöntem daha da yaygınlaşmaya başlamıștır. İşletmelerin yaklaşı \%50 oranı elle serpme şeklinde ekim yapmaktadır. İșletmelerin yaklaşık \%35’i sırt tipi atömizör ile \%15'i de gübre dağıtma makineleri ile ekim yapmaktadır. Ekim normu (dekara atılan tohum miktarı) ise çeltik tohumu çeşidine bağlı olarak 17-25 kg da-1 arasında değişmektedir. Üreticiler tohumlarını genel olarak Tarım Kredi Kooperatifi olmak üzere, Ziraat Odası Başkanlıkları, bayiiler ve üreticiler kendi yetiştirmiş oldukları üründen tohumluk seçmek suretiyle temin etmektedirler. Tohumluğun fiyatları tohum çeşidine bağlı olarak $1 \mathrm{~kg}$ fiyatı 2.5-3.5 TL arasında değişmektedir. Sertifikalı tohumluk kullanım oranı yaklaşık \%35-40 oranındadır. Yörede ekimi yapılan çeltik çeşitleri olarak çoğunlukla bölgeye has olarak tescilli olan Osmancık-97 (\%85-90) çeșidi ekilmekte olup, bunun yanında, Akçeltik, Efe, Ronaldo, Yatkın, Riba, ve Cameo çeltik çeşidi tohumlarının da ekimi yapılmaktadır. Ankette 'Ekeceğiniz çeltik çeşidinin seçiminde hangi kriterler etkili olmuştur' sorusunun cevabı olarak üreticiler sırasıyla, 'verimi, fiyatı, kalitesi ve pazar durumu' cevaplarını vermişlerdir. Ayrıca işletmelere 'Tohum temininde herhangi bir sıkıntı yaşıyor musunuz?' sorusunun cevabına tamamına yakını tohum temin etmede herhangi bir sıkıntı yaşamadıklarını beyan etmişlerdir. Çeltik tarımında münavebe uygulanmamaktadır. Aynı parsele yıllardır ekim yapılmakta olup bu da toprak ve ürün verimliliğini azaltmaktadır. Yörede sözleşmeli çeltik üretimi yapılmamaktadır. İşletmelere 'Ekimde karşılaștığınız bir sorun var mı? Varsa nelerdir?' sorusuna cevap olarak ișletmelerin \%92'si ekimde herhangi bir sorunla karşılaşmadıklarını beyan etmişler, ancak \%8'i ise çeşitli nedenlerle (işçi bulamama, su sıkıntısı çekme) karşı karşıya kaldıklarını açıklamışlardır. Ankette ayrıca 'Fideden dikimi biliyor musunuz?' sorusuna yanıt olarak çiftçilerin büyük bir kısmı bu konuda bilgi sahibi olmadıkları ve Çorum ilinde fideleme makinesinin olmadığını ifade etmişlerdir.

Gübreleme: Yüksek verim ve kaliteli bir çeltik üretebilmek için gübreleme gerekli olduğu için, işletmelerin tamamı çeltikte taban gübrelemesi yapmaktadır. Taban gübresini üreticiler elle, santrifüj gübre dağıtma makinesi ve sırt tipi atomizör ile vermektedirler. İşletmeler, taban gübrelemesinde çoğunlukla kompoze gübrelerden dekara 25-35 kg arasında 20-20-0+Zn, 20-20$10+5\left(\mathrm{SO}_{3}\right)+\mathrm{Zn}$ veya $18-46$ DAP gübresi vermektedir. Çeltik yetiştiriciliğinde üst gübrelemesi de önemli bir yer tutmaktadır. Çiftçilerin yaklaşık \%65'i üst gübreyi iki, \%25'i bir, \%10’u da üst gübreyi üç eşit parça halinde uygulamaktadırlar. Üst gübreyi çiftçiler suyu kesmeden su içinde elle vermektedir. Verilme zamanı olarak kardeşlenme dönemi ve salkım oluşum başlangıç döneminde vermektedirler. Üst gübre olarak daha çok \%21 Amonyum Sülfat ve ÜRE gübrelerini yaklaşı 25-50 kg olarak uygulamaktadırlar. Çiftçilerin $\% 5$ 'i, organik gübre olarak Humik Asit uygulaması yapmaktadır. Ankette çeltik yetiştiriciliğinde gübreleme için toprak analizi yaptırıyor musunuz?' sorusuna (\%87) çoğunluğu yaptırmadıkları, bazı üreticilerin (\%13) ise bazen 
yaptırdıklarını söylemişlerdir. Toprak analizi yaptıran çiftçilerin ise toprak analizi desteklemesinden yararlanmak için zorunlu yaptırdıklarını bildirmişlerdir. Anket yapılan işletmelerden 25 işletmede (\%22.73) çiftçilerce santrifüj gübre dağıtma makinesini kullandıkları görülmektedir. Santrifüj gübre dağıtma makinesi, gübrelemenin yanında ekim işleminde de kullanılabilmektedir.

İlaçlama: İşletmelerin çeltik yetiştiriciliğinde hastalık ve zararlılara karşı çok az bir işletme dışında ilaçlı mücadele yapmadıkları ancak yabancı otlara karşı işletmelerin tamamına yakını ilaçla mücadele yapmaktadır. Yabancı otlarla gereği gibi mücadele edilmediği takdirde \%20-30 arasında bir verim düşüklüğü görülmektedir. Bazı işletme sahipleri ilaçlı mücadelenin yanında elle yabancı otları yolmak suretiyle kültürel mücadele de uygulamaktadırlar. Yörede ve ülkede çeltik tarımında en yoğun ve sorun olarak görülen yabancl ot olarak 'Darıcan' görülmektedir. Ankete dahil olan işletmelerin \%90'1, ilaçlı mücadelede ekipman olarak sırt pompası kullanırken $\% 10$ 'u tarla pülvarizatörü kullanmaktadır. Anket uygulanan 110 işletme sahibinden 62 işletmede (\% 56.36) $15-25$ litre hacimli sırt pülvarizatörü ile 25 işletmede (\%22.73) 20-25 litre hacimlere sahip sirt tipi atomizör bulunmaktadır. 28 işletmede (\%25.45) kuyruk milinden tahrikli tarla pülverizatörü mevcuttur. Tarla pülverizatörlerin kapasitesi 300-400-600 lt olarak değişmektedir.

Sulama: Çeltik bitkisi, su içinde yetişen bir bitki olduğundan ekimden hasada yakın bir zamana kadar belli dönemler haricinde sürekli su içinde yetişir. İşletmelerin yaklaşık \%90-95'i sulama suyunu Kizılırmak akarsuyundan \%5-10'u ise yeraltı suyundan temin etmektedirler. Çeltik tarımında salma sulama yöntemi uygulanmakta olup, su yüksekliği bitkilerin gelişme dönemlerine bağlı olarak 5-15 cm'dir. İşletmeler tavalardaki suyu hasattan 15-20 gün önce kesmektedirler. İşletmelere 'Sulama ile ilgili sorunlarınız var mıdır? sorusuna yaklaşı \% $\% 25$ 'i 'Evet' cevabını vermişlerdir. Sulama ile ilgili karşılaşllan sorunlar olarak da, suyu yeraltından temin eden işletmeler enerji giderlerinin yüksek olmasından, ırmaktan temin eden işletmelerde ise yağışın yetersiz olduğu kuraklık dönemlerde ırmaktaki su seviyesinin düşük olmasıyla su temininde sıkıntılar yaşandığı ve sulama işinde iş̧̧i bulamama gibi sıkıntılarla karşılaştıklarını ifade etmişlerdir.
Hasat: Çeltik tarımında hasat dönemi olarak salkımların \%80'inin saman rengini aldığı, danedeki nem oranının \%22-24 olduğu zaman, ürün hasat olgunluğu dönemdir. Çorum yöresinde hasat tarihi Eylül ayının ortasından başlayarak Ekim ayının ortasına kadar devam etmektedir. Çeltikte hasadın gecikmesi halinde üründe kayıplar olmaktadır. İşletmelerin tamamı hasadı biçerdöverle yapmaktadır. Biçerdöver 3 işletme dışında kimsede olmadığından işletmeler ürünlerini kiralama yoluyla ücret karşılığında hasat ettirmektedir. Çorum yöresinde çeltik verimi ortalama dekara 800-850 kg arasında değişmektedir. Üreticiler ürününü öncelikli olarak Toprak Mahsülleri Ofisine, bunun dışında fabrika ve tüccarlara satmaktadırlar. Yazıcı (2006), Erzurum ili Pasinler Ovası'nda şeker pancarı üretimi yapan işletmelerin mekanizasyon durumu için işletmelerde kullanılan toprak işleme aletlerinde bir yoğunluk söz konusuyken, şeker pancarı tarımında en fazla iş gücü gerektiren bakım ve hasat işlemlerinde alet ve makine ihtiyacının zorunluluğunu ortaya koymuştur. Yapılan bu çalışmada da başta ekim olmak üzere bakım ve hasat işlemlerinde kullanılan alet ve ekipmanlara ihtiyaç olduğu görülmektedir. Bu çalışmada, çeltik tarımı yapan işletmelerde ekim, bakım ve hasat çalışmalarında yeterli tarım alet ve makinelerine sahip olunamadığı görülmektedir. Çeltik tarımında yeterli mekanizasyon zincirinin kurulabilmesiyle, makineleşme düzeyi ile beraber, traktör kullanım süresinin artması ve üretimde verim artışının sağlanabileceği söylenebilir.

Kurutma: Çeltik yetiştiriciliğinde ürün hasat edildikten sonra nem oranının düşürülmesi için ürün en kısa sürede kurutulması gerekmektedir. Ankette yer alan işletmeler ürün hasat edildikten en geç 24 saat içerisinde kurutma yapmaktadırlar. İşletmelerin \%80'i köy içindeki harman yerinde güneşte ürününü kuruturken, yaklaşık \%20'si de yörede özel olarak işletilen kurutma tesislerinde ücret karşıllğında ürünlerini kurutmaktadırlar. Günește kurutulan ürünler 4-5 cm kalınlığında serilerek tırmık veya kürekle sık sık aralıklarla karıştırma işlemi yapmaktadırlar.

\section{Sonuç}

Yapılan bu çalışmada, ankete dahil işletmelerin traktörlerin yaş ortalaması Türkiye traktör parkının ortalama yaşının oldukça altındadır. İşletmelerdeki traktörlerin ortalama motor gücünün Türkiye traktör parkı ortalama motor gücü üzerinde olduğu gözlenmiştir. İşletmelerin sahip oldukları tarım alet 
ve makineleri gruplamasına göre, her birim traktör bașina birer kulaklı pulluk ve kültüvatör düșmekte olup, her iki traktöre birer tesviye aleti düşerken, yaklaşılk her altı traktöre bir tırmık düştüğü, yaklaşık her beș traktöre bir ekim makinesi ile santrifüj gübre dağıtma makinesi, her beş traktöre dört tarla pülverizatörü ve her sekiz traktöre bir sapdöver harman makinesi düştüğü gözlenmiştir. Çeltik üretimi yapan işletmelerdeki traktör başına düşen alet-makine sayısı 4.90 adet ile, Corum ili ortalamasından daha düșük olsa da, Türkiye ortalamasından daha yüksektir. İşletmelerdeki tarımsal mekanizasyon düzeyi Çorum ili ve Türkiye ortalaması değerlerinden daha yüksek değerdedir. Çeltik üretiminde tarımsal işlemlerdeki mekanizasyon uygulamaları açısından yapılan işlemler arasında, toprak hazırlığında pulluk esaslı kombinasyonlar kullanılmakta, işletmelerin yaklaşık $\% 85$ 'i sulu ekim yapmakta olup, ekim $1 / 2$ oranında elle serpme ekim, yaklaşı $1 / 3^{\prime}$ ü sırt pompası ile yaklaşı $1 / 6^{\prime}$ 'sı ise santrifüj gübre dağıtma makineleri ile ekim yapmaktadır. Çeltik tarımında münavebe sistemi uygulanmamakta, işletmelerin tamamında çeltikte taban gübrelemesi yapılmakta ve taban gübresi elle, santrifüj gübre dağıtma makinesi ve sırt tipi atömizör ile verilmektedir. Yabancı otlara karşı işletmelerin tamamına yakını ilaçlı mücadeleyi $\% 90$ oranında sırt pompası ile yapmaktadır. İșletmelerin tamamında hasat işlemi biçerdöverle ve kiralama yoluyla yapmaktadır.

Bölgede çeltik üreticilerinin tarımsal mekanizasyon göstergelerinin Türkiye ortalamasının üzerinde olmasına karşın, iklim şartları sebebiyle ürün çesitliliğinin az olması ve üretim sezonunun kısa oluşu, traktör sayısı ve gücü bakımından traktörlerin yeterince yüklenememesine neden olmaktadır. Yörede traktörlerin yıllık kullanım sürelerinin artırmasını sağlamanın en etkili yolları, traktörü etkin ve yeterli biçimde yükleyebilecek tarım makineleri parkına sahip olmak ve ortak makine kullanımını geliştirmek ve yaygınlaştırmaktır. Üreticilerin tarımsal üretimde kullandıkları parkta yer alan makine sayısını arttırabilmek için, traktör ve tarım alet-makinelerini ekonomik kullanım süreleri sonunda hurdaya ayırarak yerlerine yenilerini alabilmesi, ekonomik anlamda desteklenmesi, bu anlamda hibe ve teșvik desteklerinden yararlanabilmesi, işletmelerin mekanizasyon düzeylerini ve mekanizasyon zincirini tamamlayabilmeleri açısından olumlu sonuçlar doğuracaktır. Çeltik üreticilerinin arazilerinin dağınık ve parçalı olması, mekanizasyonu sinırlayarak üretim verimliğinin düşmesine neden olmaktadır. Bu bakımdan arazi toplulaştırmalarının da bir an evvel yapilarak bu sorunun giderilmesi sağlanmalıdır. Devletin makine desteklemeleri yanında bu konuda özellikle mazot ve gübre fiyatlarında çiftçi lehine desteklemelerinin daha da arttırılması sağlanmalıdır. İlgili kurum ve kuruluşların gerek mekanizasyon konusunda gerekse üretimle ilgili konularda çiftçilere eğitim ve yayım çalışmalarının yapılması da önemlidir. Sonuç olarak, yapılan bu çalışmada, çeltik üretimi yapan işletmelerin tarımsal işlemleri (toprak hazırlığı, ekim-bakım gübreleme, ilaçlama, sulama, hasatharman ve depolama işlemlerindeki mekanizasyon uygulamaları) açısından işletmelerin tam anlamıyla yeterli mekanizasyon zincirini tamamlayamadıkları görülmektedir. Çeltik tarımında mekanizasyon zincirinin tamamlanması durumunda, gerek mekanizasyon düzeyi açısından gerekse üretim verimliliği açısından önemli düzenlemeler sağlanacaktır. Bu konuda araştırma sonuçlarının Bakanlık, Üniversite ve çiftçi üçgeninde değerlendirilmesi ve yeterli bir ișbirliğinin sağlanmasının gerekliliği söz konusudur.

\section{Kaynaklar}

Akar, M., 2015. Muş Ovası'nın Tarımsal Mekanizasyon Özellikleri Ve 12 Hektar Büyüklüğünde Bir İşletme İçin En Uygun Bitki Deseninin Belirlenmesi. Yüksek Lisans Tezi, Atatürk Üniversitesi Fen Bilimleri Enstitüsü Tarım Makinaları Anabilim Dalı, s. 101. Erzurum.

Anonim, 2016. Toprak Mahsülleri Ofisi 2016 Yılı Hububat Raporu www.tmo.gov.tr/Upload/Document/ hububat /hububatraporu2016.pdf.

Altunışık, R., Coşkun, R., Bayraktaroğlu, S., Yıldırım, E., 2012. Sosyal Bilimlerde Araştırma Yöntemleri Sakarya Üniversitesi İşletme Fakültesi, 7. Baskı.

Altuntaş, E., Aslan, İ. 2009. Sivas İlinin Tarımsal Mekanizasyon Düzeyinin 1997-2007 Ylları Arasındaki Değişiminin İncelenmesi. GOÜ Ziraat Fakültesi Dergisi, 26 (2): 87-95.

Altuntaş, E., 2016. Türkiye'nin Tarımsal Mekanizasyon Düzeyinin Coğrafik Bölgeler Açısından Değerlendirilmesi. Türk Tarım - Gıda Bilim ve Teknoloji Dergisi, 4 (12): 1157-1164.

Bayhan, Y., 1993. Çukurova Bölgesinde Çeltik Üretiminde Mekanizasyon Sorunlarının Değerlendirilmesi Üzerine Bir Araștırma. Yüksek Lisans Tezi, Atatürk 
Üniversitesi Fen Bilimleri Enstitüsü Tarım Makinaları Anabilim Dalı, Tekirdağ.

Chimeddamba, B., 2012. Moğolistan' ın Tarımsal Yapısı ve Buğday Tarımındaki Mekanizasyon Düzeyi. Yüksek Lisans Tezi, Ege Üniversitesi Fen Bilimleri Enstitüsü Tarım Makinaları Anabilim Dalı, İzmir.

Culpin, C. 1975. Profitable Farm Mechanization. Granada Publ. 3rd Ed. ISBN 024611571 8, Great Britain.

Çalışır, S., Güney, M., Aydın, C., 1991. Konya Bölgesinin Tarımsal Mekanizasyon Sorunları ve Çözüm Önerileri, Tarımsal Mekanizasyon 13. Ulusal Kongresi, 489-501, Konya.

Çiçek, G., Çelen, İ. H., 2000. Trakya bölgesindeki Çeltik İşletmelerinin Mekanizasyon Durumu. Türk-Koop Ekin Dergisi, Sayı: 13. Temmuz-Eylül 2000. Ankara.

Dartar, İ., Say S.M., 2008. Türkiyenin Tarımsal Mekanizasyon Düzeyinin Değerlendirilmesi ve Coğrafi Bilgi Sistemi ile Haritalanması. Çukurova Üniversitesi Fen ve Mühendislik Bilimleri Dergisi. 19(1),134-142.

Demir, B., Öztürk, İ., 2011. Samsun ili tarımsal mekanizasyon özelliklerinin yıllara göre değişimi, Samsun Sempozyumu, 1-7.

Durgut, M.R., Arın, S., 2005. Trakya Bölgesi Bağcllı̆̆ının Mekanizasyon Düzeyi ve Sorunları, Trakya Üniversitesi Tekirdağ Ziraat Fak. Dergisi 2(3): 1-7

Evcim, H.Ü., 2008. Türkiye Yaşlı Traktör Parkı Yenilenme İhtiyacı ve Çözüm Önerisi. Türk Traktör ve Zir.Mak.A.Ş., Ankara, 5 s.

Işık, E., Güler, T., Ayhan, A., 2003. Bursa İline İlişkin Mekanizasyon Düzeyinin Belirlenmesine Yönelik Bir Çalışma, Uludağ Üniv. Zir. Fak. Derg., 17(2): 125-136 Bursa.

İleri, M.S., 2009. Türk Tarım Alet ve Makinaları İmalatçıları Birliği Tarım Makinaları Sektör Raporu.

(http://www.tarmakbir.org). Erişim Tarihi: 21.10.2015.

Kadayifçilar, S., Öztürk R., ve Acar, A.İ., 1990. Tarımsal Mekanizasyon Derecesinin Değerlendirilmesi. Tarım Makinaları Bilim ve Tekniği Dergisi, 2 (1), 1 4, Ankara.

Kasap, A., Demir, A., Dilmaç, M., 1997. Tokat İlinde Tarımda Makinalaşmanın Genel Yapısı ve Sorunları Üzerine Bir Araştırma. Tarımsal Mekanizasyon 17. Ulusal Kongresi, Bildiri Kitabı, s. 35-43, Tokat.

Özgüven, M.M., Türker, U., Beyaz, A., 2010. Türkiye'nin tarımsal yapısı ve mekanizasyon durumu. GOÜ Ziraat Fakültesi Dergisi, 28: 2, 89-100.
Sabanci, A., Sümer, S. K., Say, S. M., Has, M., 2003. Türkiye'de Ekonomik Traktör Parkı ve Gelișimi. Tarımsal Mekanizasyon 21. Ulusal Kongresi, S:125138, Konya.

Sağlam, C., Çevik, M.Y., 2012. Şanlıurfa'daki Çiftçilerin Traktör Satın Alma Davranışlarına Etkili Faktörlerin Belirlenmesi. Harran Üniversitesi Ziraat Fakültesi Dergisi, 16 (1): 1-8.

Topuz, N., 1997. Ege Bölgesinde Zeytin Mekanizasyon Düzeyinin Tespit Edilmesi. Yüksek Lisans Tezi, Ege Üniversitesi Fen Bilimleri Enstitüsü Tarım Makinaları Anabilim Dalı, İzmir.

TÜİK, 2016. http://rapory.tuik.gov.tr/13-11-2017

Ulusoy, E., Evcim, H.Ü., Yazgl, A., İleri, M.S., Sabancı, A., Acar, A.İ. 2010. Traktör ve Tarım Makinaları İmalat Sanayinin Bugünü ve Geleceği. Ziraat Mühendisliği VII. Teknik Kongresi", 11-15 Ocak, Ankara.

Ülger, P., Kayişoğlu, B., Eker, B., Akdemir, B., Pinar, Y., Bayhan, Y., Sağlam, C., 1996. Tarım Makinaları İlkeleri, T.Ü. Tekirdağ Ziraat Fakültesi, Ders Kitabı, No:29, S:435, Fakülteler Matbaası, İstanbul.

Ünal, G. H., Saçlık, K., 2007. Kastamonu İli Tarımsal İşletmelerinin Tarımsal Yapı ve Mekanizasyon Özellikleri, Tarımsal Mekanizasyon 24. Ulusal Kongresi, 3846, Kahramanmaraş.

Yaoming, L., 2003. The Status And Prospects Of Rice Production Mechanization in China. http//www.irri.org.

Yazıcı, N., 2006. Erzurum İli, Pasinler Ovası'nda Şeker Pancari Tarimi Yapan Tarımsal İșletmelerin Mekanizasyon Düzeylerinin Tespit Edilmesi. Yüksek Lisans Tezi, Atatürk Üniversitesi Fen Bilimleri Enstitüsü Tarım Makinaları Anabilim Dalı, Tekirdağ.

Yıldız, C., 2002. Pasinler İlçesinde Bitkisel Üretim Yapan İşletmelerde Ortak Makina Kullanımı, Ortak Makina Kullanımında Karşılaşılan Sorunlar, İşletmelerin Sosyal ve Ekonomik Yapısına En Uygun Makina Kullanım Modelinin Tespiti. Yüksek Lisans Tezi, Atatürk Üniversitesi Fen Bilimleri Enstitüsü Tarım Makinaları Anabilim Dalı, Erzurum.

Yıldız, C., Öztürk İ., Erkmen, Y., 2005. VI. ve VII. 1991-2001. Genel Tarım Sayımı Sonuçlarına Göre Türkiye'nin Tarımsal Yapı ve Mekanizasyon Durumundaki Değișmeler. Harran Üniversitesi Ziraat Fakültesi GAP IV. Tarım Kongresi, Cilt:1, S:644-651, Şanlıurfa.

Zeren, Y., Tezer, E., Tuncer, İ.K., Evcim, Ü., Güzel, E., Sındır, K.O., 1995. Tarım Alet-Makine ve Ekipman Kullanım ve Üretim Sorunları. Ziraat Mühendisliği Teknik Kongresi, Ankara. 